\title{
Profile of thyroid hormones in breast cancer patients
}

P.P. Saraiva ${ }^{1}$, N.B. Figueiredo ${ }^{2}$, C.R. Padovani ${ }^{3}$, M.M. Brentani ${ }^{4}$ and C.R. Nogueira ${ }^{2}$

\section{Correspondence}

C.R. Nogueira

Departamento de Clínica Médica UNESP

Distrito de Rubião Júnior, $\mathrm{s} / \mathrm{n}$

18618-970 Botucatu, SP

Brasil

Fax: +55-14-6821-3744

E-mail: nogueira@fmb.unesp.br

Publication supported by FAPESP. $\ldots \ldots \ldots \ldots \ldots \ldots \ldots$

Received January 30, 2004 Accepted January 3, 2005
'Disciplina de Periodontia, Departamento de Odontologia, Universidade Sagrado Coração, Bauru, SP, Brasil

${ }^{2}$ Disciplina de Endocrinologia, Departamento de Clínica Médica, and

${ }^{3}$ Disciplina de Bioestatística, Departamento de Bioestatística,

Universidade Estadual Paulista, Botucatu, SP, Brasil

${ }^{4}$ Disciplina de Oncologia, Departamento de Radiologia,

Faculdade de Medicina, Universidade de São Paulo, São Paulo, SP, Brasil

\section{Abstract}

Estrogen involvement in breast cancer has been established; however, the association between breast cancer and thyroid diseases is controversial. Estrogen-like effects of thyroid hormone on breast cancer cell growth in culture have been reported. The objective of the present study was to determine the profile of thyroid hormones in breast cancer patients. Serum aliquots from 26 patients with breast cancer ranging in age from 30 to 85 years and age-matched normal controls $(\mathrm{N}=22)$ were analyzed for free triiodothyronine $\left(\mathrm{T}_{3} \mathrm{~F}\right)$, free thyroxine $\left(\mathrm{T}_{4} \mathrm{~F}\right)$, thyroid-stimulating hormone (TSH), antiperoxidase antibody (TPO), and estradiol $\left(\mathrm{E}_{2}\right)$. Estrogen receptor $\beta(\mathrm{ER} \beta)$ was determined in tumor tissues by immunohistochemistry. Thyroid disease incidence was higher in patients than in controls $(58 v s 18 \%, \mathrm{P}<0.05)$. Subclinical hyperthyroidism was the most frequent disorder in patients (31\%); hypothyroidism (8\%) and positive anti-TPO antibodies (19\%) were also found. Subclinical hypothyroidism was the only dysfunction (18\%) found in controls. Hyperthyroidism was associated with postmenopausal patients, as shown by significantly higher mean $\mathrm{T}_{3}$ and $\mathrm{T}_{4}$ values and lower TSH levels in this group of breast cancer patients than in controls. The majority of positive ERß tumors were clustered in the postmenopausal patients and all cases presenting subclinical hyperthyroidism in this subgroup concomitantly exhibited Erß-positive tumors. Subclinical hyperthyroidism was present in only one of 6 premenopausal patients. We show here that postmenopausal breast cancer patients have a significantly increased thyroid hormone/ $\mathrm{E}_{2}$ ratio $(\mathrm{P}<0.05)$, suggesting a possible tumor growth-promoting effect caused by this misbalance.

Growing and developing breasts require the coordinated action of several hormones such as prolactin, estrogen $\left(\mathrm{E}_{2}\right)$, progesterone, adrenal steroids, insulin, and growth and thyroid hormones (1). $\mathrm{E}_{2}$ is considered to
Key words - Thyroid hormone - Estrogen receptor - Breast cancer - Hyperthyroidism ..................... be a potent mitogen for the normal mammary gland, whereas thyroid hormones appear to stimulate lobular development, contributing to the differentiation of normal breast tissue (2). The biological activity of thyroid hor- 
mones and $E_{2}$ is only manifested in cells expressing thyroid hormone (TR) and estrogen receptors (ER), respectively, that belong to the nuclear receptor superfamily. These receptors share a common mechanism of action whereby hormone-receptor complexes bound to cis acting DNA elements enhance or repress transcription of target genes (3).

As the half-site of the consensus sequence of nucleotide bases constituting the thyroid hormone response element is identical to the ER response element half-site, TR has been shown to bind to ER response elements in addition to their cognate response elements (4). Since various isoforms of both ER and TR exist, combinations of different ER and TR isoforms could lead to different transcriptional end points (5). There are four major TR subtypes, TR $\alpha 1, \alpha 2, \beta 1$, and $\beta 2$, that are encoded by different genes (6). Two ER isoforms, $\alpha$ and $\beta$, arising from two differential genes exist in vertebrates (5).

The involvement of $E_{2}$ in breast cancer growth has been established. About one third of breast cancers maintain $\mathrm{E}_{2}$ dependence for growth and the concentration of ER in malignant breast tissues is an indicator of their hormonal dependence (3). However, the relationship between breast cancer and thyroid hormone is controversial. Even though many studies have shown that thyroid diseases are common in women with breast cancer, other reports have not confirmed this association (reviewed in 7,8). Almost every form of thyroid disease including hyperthyroidism has been identified in association with breast cancer (9-11). Moreover, hyperthyroidism accounts for $2 \%$ of all patients presenting adult gynecomastia (12) and it has also been suggested that free triiodothyronine $\left(\mathrm{T}_{3}\right)$ plays an important role in the physiology of fibrocystic breast disease (13). Consistent with the proposal that thyroid hormones act on the breast, TR have been described in breast cancer (14).

There are reports on interference between estradiol and thyroid hormones. Previous studies suggested a cross talk between ER and TR in neuroendocrine tissues leading to inhibition of estrogenic effects by thyroid hormone (15). On the other hand, physiological concentrations of $T_{3}$, the more active form of thyroid hormone, significantly enhance estradiol growth stimulation of a number of human breast carcinoma cell lines (16). In T47D breast cancer cells, $\mathrm{E}_{2}$ and $\mathrm{T}_{3}$ similarly regulate cell cycle progression and proliferation raising the p53 level and causing hyperphosphorylation of $\mathrm{pRb}$ (17).

We have demonstrated that in breast cancer cell lines, $\mathrm{T}_{3}$ at supraphysiologic concentrations and in the absence of $\mathrm{E}_{2}$ mimics the effects of $E_{2}$, possibly through the ER (18). To continue our study of the association between thyroid hormones and breast cancer, the aim of the present investigation was to analyze the thyroid hormone profile of breast cancer patients.

Patients included in the present study ( $\mathrm{N}$ =26) were newly diagnosed and submitted to surgery at Hospital das Clínicas, School of Medicine, UNESP, Botucatu, SP, Brazil. All cases were classified as stage II. Ages ranged from 30 to 85 years, and 20 patients were menopausal (amenorrhea for at least one year). The study was approved by the Hospital Ethics Committee and all patients signed an informed consent form.

Patients were excluded for the following reasons: radio- or chemotherapy before surgery, hormonal replacement, any kind of previously diagnosed thyroid disease, chronic kidney failure, or recent elevation of serum creatinine to values greater than normally expected for that particular age. Other exclusion factors were: abnormal hepatic function shown by AST, ALT, bilirubin, and/or alkaline phosphatase concentrations higher than twice the normal upper limit; use of blocking agents, aspirin, heparin, phenytoin, steroids, or dopamine, taken one month before starting or during the study; use of iodine contrasts for a 6-month period before and during the study. 
Serum aliquots were analyzed for $\mathrm{T}_{3}$, free thyroxine $\left(\mathrm{T}_{4} \mathrm{~F}\right)$, thyroid-stimulating hormone (TSH), $\mathrm{E}_{2}$, and antiperoxidase antibody (anti-TPO) using commercially available kits (DPC, Los Angeles, CA, USA). The normal ranges were $1.4-4.4 \mathrm{pmol} / \mathrm{ml}$ for $\mathrm{T}_{3} \mathrm{~F}, 0.8-2.0 \mathrm{ng} / \mathrm{dl}$ for $\mathrm{T}_{4} \mathrm{~F}$, and $0.3-5.0 \mu \mathrm{U} /$ $\mathrm{ml}$ for TSH. Serum determinations were performed prior to surgery, radiotherapy, and chemotherapy. After surgery, new serum determinations were performed in order to confirm the previous data. For the control group, 22 women aged 30 to 85 years were selected (4 premenopausal and 18 postmenopausal women) whose recent mammograms indicated absence of breast cancer. These mammograms were performed in the same week when anamnesis and blood samples were collected. There was no difference in $\mathrm{E}_{2}$ levels between controls and patients. Premenopausal patients presented $\mathrm{E}_{2}$ levels of $17.63 \pm 33.66$ and controls $24.80 \pm 3.65 \mathrm{pg} /$ $\mathrm{ml}$. The mean values found in postmenopausal control women and in breast cancer patients were $21.80 \pm 12.00$ and $13.03 \pm$ $46.99 \mathrm{pg} / \mathrm{ml}$, respectively.

The presence of ER in tumors was determined by immunohistochemical staining using a polyclonal rabbit anti-human ERß antibody (Upstake Biotechnology, Inc., Lake Placid, NY, USA). Biotinylated secondary antibodies (anti-mouse IgG or anti-rabbit IgG) were obtained from Vector Laboratories (Burlingame, CA, USA). The reactions were developed with the avidin-biotin-peroxidase complex. Tumors known to be positive for the studied marker were considered to be positive controls.

Mean serum thyroid hormone values were $3.56 \pm 3.14 \mathrm{pmol} / \mathrm{ml}$ for $\mathrm{T}_{3} \mathrm{~F}, 1.40 \pm 1.64 \mathrm{ng} /$ $\mathrm{dl}$ for $\mathrm{T}_{4} \mathrm{~F}$ and $1.36 \pm 0.63 \mu \mathrm{U} / \mathrm{ml}$ for $\mathrm{TSH}$ in breast cancer patients and $2.87 \pm 3.12 \mathrm{pmol} /$ $\mathrm{ml}, 1.10 \pm 0.83 \mathrm{ng} / \mathrm{dl}$ and $2.41 \pm 0.35 \mu \mathrm{U} / \mathrm{ml}$, respectively, in controls. Anti-TPO antibodies were not found in controls. $\mathrm{T}_{3} \mathrm{~F}$ levels were significantly higher in patients than in controls $(\mathrm{P}<0.001$, Mann-Whitney test).
In Table 1, patients and controls were classified by menopausal status, and $\mathrm{T}_{3} \mathrm{~F}$, $\mathrm{T}_{4} \mathrm{~F}$ and TSH levels were compared between the two groups. There was a clear association between hyperthyroidism and menopausal status, with postmenopausal patients presenting a statistically significant subclinical hyperthyroidism compared to controls. TSH levels in postmenopausal patients were lower than in both controls and premenopausal patients; 8 of 20 patients presented subclinical levels, defined by TSH $<0.4 \mu \mathrm{U} /$ $\mathrm{ml}$. Nonparametric analysis of variance was used for the two-factor model $(\mathrm{P}<0.05$; Mann-Whitney test). Postmenopausal patients had a significantly higher $\mathrm{T}_{3} \mathrm{~F} / \mathrm{E}_{2}$ ratio than controls.

Table 2 shows that $58 \%$ of the patients with breast cancer (15 patients) presented some kind of thyroid hormone-related pathology, whereas in the control group hypothyroidism (18\%) was the only thyroid disorder observed. Subclinical hyperthyroid-

Table 1. Serum thyroid hormone levels in breast cancer patients and control individuals classified by menopausal status.

\begin{tabular}{lccccc}
\hline & \multicolumn{2}{c}{ Postmenopausal women } & & \multicolumn{2}{c}{ Premenopausal women } \\
\cline { 2 - 3 } & $\begin{array}{c}\text { Breast cancer } \\
(\mathrm{N}=20)\end{array}$ & $\begin{array}{c}\text { Control } \\
(\mathrm{N}=18)\end{array}$ & & $\begin{array}{c}\text { Beast cancer } \\
(\mathrm{N}=6)\end{array}$ & $\begin{array}{c}\text { Control } \\
(\mathrm{N}=4)\end{array}$ \\
\hline $\mathrm{T}_{3} \mathrm{~F}$ & $3.91 \pm 1.64^{*}$ & $2.84 \pm 0.82$ & & $3.33 \pm 0.97$ & $2.97 \pm 0.69$ \\
$\mathrm{~T}_{4} \mathrm{~F}$ & $1.43 \pm 0.63^{*}$ & $1.10 \pm 0.20$ & & $1.31 \pm 0.33$ & $1.30 \pm 0.30$ \\
$\mathrm{TSH}^{\mathrm{TS}}$ & $1.00 \pm 2.11^{*}$ & $2.86 \pm 3.12$ & & $1.82 \pm 2.44^{*}$ & $1.14 \pm 0.26$ \\
$\mathrm{~T}_{3} \mathrm{~F} / \mathrm{E}_{2}$ & $0.33 \pm 2.64^{*}$ & $0.13 \pm 0.06$ & & $0.18 \pm 0.36$ & $0.14 \pm 0.03$
\end{tabular}

Data are reported as median \pm total semi-range. $T_{3} F=$ free triiodothyrosine $(\mathrm{pmol} / \mathrm{ml})$; $\mathrm{T}_{4} \mathrm{~F}=$ free thyroxine $(\mathrm{ng} / \mathrm{dl}) ; \mathrm{TSH}=$ thyroid-stimulating hormone $(\mu \mathrm{U} / \mathrm{ml}) ; \mathrm{T}_{3} \mathrm{~F} / \mathrm{E}_{2}=$ ratio of free triiodothyrosine and estrogen $\left(E_{2}\right)$.

${ }^{*} \mathrm{P}<0.05$ compared to control group (Mann-Whitney test).

Table 2. Distribution of thyroid hormone dysfunction in patients with breast cancer and controls.

\begin{tabular}{lcr}
\hline & Breast cancer & Control \\
\hline Thyroid dysfunction & $15(58 \%)^{*}$ & $4(18 \%)$ \\
Absence of thyroid dysfunction & $11(42 \%)$ & $18(82 \%)$ \\
\hline${ }^{*} P<0.05$ compared to control group (Fisher's exact test). &
\end{tabular}


ism was the most frequent disorder, being present in 8 of the $26(31 \%)$ breast cancer patients. Seven of these were postmenopausal patients, whereas only 1 (15\%) of the six premenopausal patients had hyperthyroidism. Hypothyroidism was detected only in the postmenopausal group ( 2 cases) whereas anti-TPO antibodies were identified in two and three post- and premenopausal patients, respectively. Thyroid dysfunction was found to be significantly higher in patients with breast cancer. Data analysis was performed by Fisher's exact test $(\mathrm{P}<0.05)$.

ERß immunostaining of tumor tissues from all patients indicated ER+ in 17/26 $(65 \%)$ cases, 14 of which were classified as postmenopausal; this group included all patients with subclinical hyperthyroidism. On the other hand, patients displaying TPO antibodies had tumors classified as ER negative, independent of menopausal status and in the absence of thyroid hormone dysfunction.

Considering the control and experimental patients as a whole, $12.5 \%$ presented subclinical hypothyroidism, a higher occurrence than described in population studies (4.7\%) (19). However, most of our patients were postmenopausal and hypothyroidism is a common hormonal alteration in patients over 50 years of age (20). This higher incidence may also derive from the fact that all the patients in this study came from an area known to be endemic for low iodine ingestion.

In conclusion, subclinical hyperthyroid- ism was the only statistically significant thyroid alteration found in our breast cancer population. This, together with the fact that the majority of patients with subclinical hyperthyroidism were postmenopausal, showed that the normal ratio between thyroid hormone and $E_{2}$ serum concentration was enhanced in these patients due to increased serum thyroid hormone and reduced $\mathrm{E}_{2}$ concentration. We may speculate that subclinical hyperthyroidism in postmenopausal patients contributes to breast tumor growth. This might result from an $\mathrm{E}_{2}$-like effect through the interactions between $\mathrm{T}_{3} / \mathrm{T}_{4}$ and the ER since the tumors in this patient subgroup expressed ERß+. These interactions may imply binding of $\mathrm{T}_{3}$ to ER, as reported for breast cancer cell lines (18). Alternatively, thyroid hormones might stimulate the transcription of ERß-dependent genes through a combination of ERß-TR $\alpha 1$, as suggested by Vasudevan et al. (5). Dinda et al. (17) postulated that the estrogen-like effects of $T_{3}$ were mediated by TR interaction with ER response element. Therefore, another possibility is that $T_{3}$ bound to the $T_{3}$ receptor, independently of ER, stimulates ER response element function, promoting transcription of target genes that lead to cellular proliferation.

Our results suggest the existence of a biological link between breast cancer in postmenopausal women and subclinical hyperthyroidism. However, further studies are required to confirm this association.

\section{References}

1. Lai LC (2002). Role of steroid hormones and growth factors in breast cancer. Clinical Chemistry and Laboratory Medicine, 10: 969974.

2. Neville MC, McFadden TB \& Forsyth I (2002). Hormonal regulation of mammary differentiation and milk secretion. Journal of Mammary Gland Biology and Neoplasia, 1: 49-66.

3. Jensen EV, Cheng G, Saji S, Mäkelä S, Noorden SV, Wahlström T, Warner M, Coombes RC \& Gustafsson J (2001). Estrogen receptors and proliferation markers in primary and recurrent breast cancer.
Proceedings of the National Academy of Sciences, USA, 98: 1519715202.

4. Glass CK \& Holoway JM (1990). Regulation of gene expression by the thyroid hormone receptor. Biochimica et Biophysica Acta, 1032: 157-176.

5. Vasudevan N, Koibuchi N, Chin WW \& Pfaff DW (2001). Differentia crosstalk between estrogen receptor (ER) alpha and ER beta and the thyroid hormone receptor isoforms results in flexible regulation of the consensus ERE. Brain Research. Molecular Brain Research, 
95: 9-17

6. Lazar MA (1993). Thyroid hormone receptors: multiple forms, multiple possibilities. Endocrine Reviews, 14: 184-193.

7. Gogas J, Kouskos E, Tseleni-Balafouta S, Markopoulos C, Revenas K, Gogas G \& Kostakis A (2001) Autoimmune thyroid disease in women with breast carcinoma. European Journal of Surgical Oncology, 27: 626-630.

8. Turken O, Narln Y, Demlrbas S, Onde ME, Sayan O, Kandemir EG, Yaylacl M \& Ozturk A (2003). Breast cancer in association with thyroid disorders. Breast Cancer Research, 5: R110-R113.

9. Takatani O, Okumoto $T$, Kosano $H$, Nishida M, Hiraide $H$ \& Tamakuma S (1989). Relationship between the levels of serum thyroid hormones or estrogen status and the risk of breast cancer genesis in Japanese woman. Cancer Research, 49: 3109-3112.

10. Cengiz O, Bozkurt B, Unal B, Yildirim O, Karabeyoglu M, Eroglu A, Kocer B \& Ulas M (2004). The relationship between prognostic factors of breast cancer and thyroid disorders in Turkish women. Journal of Surgical Oncology, 870: 19-25.

11. Goldman MB (1990). Thyroid diseases and breast cancer. Epidemiologic Reviews, 12: 16-28.

12. Ismail AA \& Barth JA (2001). Endocrinology of gynaecomastia. Annals of Clinical Biochemistry, 38: 596-607.

13. Martinez L, Castilla JA, Gil T, Molina J, Alarcon JL, Marcos C \& Herruzo A (1995). Thyroid hormones in fibrocystic breast disease. European Journal of Endocrinology, 6: 673-676.
14. Silva JM, Dominguez G, Gonzalez-Sancho JM, Garcia JM, Silva J, Garcia-Andrade C, Navarro A, Muñoz A \& Bonilla F (2002). Expression of thyroid hormone receptor/erbA genes is altered in human breast cancer. Oncogene, 21: 4307-4316.

15. Morgan MA, Dellovade TL \& Pfaff W (2000). Effect of thyroid hormone administration on estrogen-induced sex behavior in female mice. Hormones and Behavior, 37: 15-22.

16. Shao Z, Sheikh MS, Rishi AH, Dawson MI, Li X, Wilber JF, Feng P \& Fontana JA (1995). Thyroid hormone enhancement of estradiol stimulation of breast carcinoma proliferation. Experimental Cell Research, 218: 1-8.

17. Dinda S, Sanchez A \& Moudgil V (2002). Estrogen-like effects of thyroid hormone on the regulation of tumor suppressor proteins, p53 and retinoblastoma, in breast cancer cells. Oncogene, 21: 761768.

18. Nogueira CR \& Brentani MM (1996). Triiodothyronine mimics the effects of estrogen in breast cancer cell lines. Journal of Steroid Biochemistry and Molecular Biology, 59: 271-279.

19. Rivolta G, Cerutti R, Colombo R, Miano G, Dionisio P \& Grossi E (1999). Prevalence of subclinical hypothyroidism in a population living in the Milan metropolitan area. Journal of Endocrinological Investigation, 22: 693-697.

20. Bonar BD, McColgan B, Smith DF, Darke C, Guttridge MG, Willians $H$ \& Smyth PP (2000). Hypothyroidism and aging: the Rosses' survey. Thyroid, 10: 821-827. 